\title{
Transnational actors in global environmental politics 1
}

Lucy Ford

\section{Introduction}

After a month long campaign by indigenous and environmental activists to prevent an access pipeline from being drilled under the Missouri River in North Dakota, the Army Corp of Engineers refused the permit on 4 December 2016, handing initial victory to the protesters (Wong 2016). Commenting on this success, Shannon Jackson, Executive

Director of Our Revolution, a movement to reclaim democracy in the United States, stated:

Today's decision clearly demonstrates the power of the political revolution. When people come together from all walks of life - veterans, Native Americans, environmentalists, farmers, young and old - to protect the health of our planet and generations to come, there is nothing we cannot accomplish. This victory sends a clear signal to those at the top: we are united and not giving up. We will continue to stand together and expect the decisions made by our government to benefit all of us, not just the rich and corporations.

Not two months later, on 24 January 2017, US president Donald Trump overturned the verdict of the experts and ignored the voices of the water protectors by signing the executive order to approve the pipeline, demonstrating support for the fossil fuel industry (Eilperin and Dennis 2017). At this time, Trump also hinted at his intention to withdraw from the Paris Climate Agreement. 
Across the ocean in Europe, water and earth protectors are resisting the first fracking site in Lancashire, UK, after successful local government opposition to Cuadrilla's application to drill for shale gas was overruled by the UK central government (Ambrose 2017).

Environmental politics, whether national or international, it would seem then, still lies in the hands of the state, much in line with traditional, state-centric realist international relations (IR) theory. And yet, clearly, other actors have influenced these processes, from the water protectors attempting to halt projects, to the gas and oil companies successfully lobbying governments to go ahead.

Liberal and critical approaches to IR want to highlight that beyond the realm of interstate politics there is an array of actors, such as transnational social movements, nongovernmental organizations (NGOs) or transnational corporations (TNCs), sometimes collectively referred to as non-state actors, transnational actors or civil society actors, that have a bearing on politics and political outcomes. Questions about 'who acts and how' are fundamentally about what constitutes 'the political' in global environmental politics.

This chapter is concerned with transnational actors in global environmental politics. The first section of the chapter starts by locating transnational actors in IR, defining more clearly some of the key concepts and how these have evolved over time, and how they 
relate to developments within the discipline of IR. It further provides some conceptual tools for analyzing the role of transnational actors in global environmental politics, including contested theoretical approaches and challenges to explaining their significance. In particular, it analyzes the sphere of global civil society, where transnational actors are said to be located. The second section then focuses on a variety of transnational actors, including transnational environmental movements, NGOs and transnational corporate actors. It asks what motivates them and how they act and engage in global environmental politics.

\section{Locating transnational actors in international relations}

The discipline of IR is notorious for its confusing variety of concepts that are sometimes used interchangeably and sometimes mean different things. So, for example, while International Relations in its origin was concerned with analyzing the international relations between nation-states as well as their interactions with international organizations such as the UN (United Nations) or NATO (North Atlantic Treaty Organization), more recent scholars now often understand International Relations to be about social, economic, cultural or political interactions across the globe. They might want to talk about transnational politics, world politics, global politics or indeed global political economy. Similarly, the term non-state actor can be confusing. Although strictly it appears to be referring to any actor that is not a state or government, the boundaries between what constitutes state and non-state are not always clear. For example, the UN might be seen as a non-state actor in that it stands alone as an institution. However, it is clearly an international - indeed intergovernmental - organization 
and a channel through which states (and other actors) operate. The UN claims moral authority over world politics. It is, as it were, the closest body to a world government. Some would argue that international organizations, such as the UN, the World Bank, the IMF or the WTO, embody a quasi world state that holds a lot of power to direct world affairs (see, for example, Shaw 2000).

However, there are many non-state actors who contest this concentrated global power. Non-state actors championing a particular issue, such as the environment, are challenging nation-states and, by extension, inter-state organizations - claiming they are failing to solve global issues. Their aim is to contest the agenda, to point out where these institutions are failing, to promote reform of these institutions, to work with these organizations, sometimes bypassing the nation-state, and sometimes even calling for these organizations to be abolished, as seen, for example, in the 'WTO - Shrink or Sink' campaign, organized and signed by a transnational, heterogeneous collection of networks, associations and NGOs, self-defined as transnational civil society (see, for example, TWN, no date). When defining transnational actors, then, we are referring to all those non-state actors, such as TNCs, NGOs or social movements, that operate across the globe and form part of global politics. They are neither states nor international organizations, but they act alongside them, sometimes collaborating with and sometimes challenging them, and at other times ignoring them altogether.

The evolution of some of the key concepts to do with understanding transnational actors can usefully be related to the historical development of the discipline of IR in general and global environmental politics in particular. Within IR, the study of transnational 
actors came to the fore during the 1970s with the theoretical developments of pluralism and complex interdependence (Keohane and Nye 1977). Out of this developed the study of international regime theory, which focuses on the importance of institutions and shared norms amongst actors (see Vogler, Chapter 1 in this volume). The emphasis in this body of literature is on the effectiveness of international institutions that deal with transboundary issues and the institutional settings and arrangements as well as power structures that enable or constrain international cooperation. In the field of the environment, this literature looks particularly at international environmental regimes, or Multilateral Environmental Agreements (MEAs) as they are most often referred to. While much of regime theory stands accused of state-centrism, there is within this school of thought acknowledgement of the role of non-state actors, known as epistemic communities. They are transnational networks of knowledge-based experts from the world of science, NGOs or business that contribute expertise to the policy-making process in particular issue areas, such as the environment, trade or security, which fosters institutional and wider institutional learning (for example Vogler 2003).

\section{From international regimes to global governance}

The analytical framework of international regimes has tended to be replaced by that of global governance. The concept of governance has become prominent in IR since the end of the Cold War. No longer was the world seen as divided into a simple bi-polar system maintaining international order. A lot of the literature has focused on how processes of globalization are generating a more complex, multi-level world political system which implicitly challenges the old Westphalian assumptions about the nation- 
state. Questions about how to govern the new world order have become prominent, not least in relation to transboundary issues, such as environmental degradation.

Governance as a concept is distinguished from government. A government is backed by formal authority; by police powers to ensure implementation of policies. Governance, on the other hand, is more encompassing than government, including institutions as well as non-governmental mechanisms. Held and McGrew (2003: 8) describe governance as

$[\mathrm{T}]$ he structures and processes of governing beyond the state where there exists no supreme or singular political authority ... it constitutes a broad analytical approach to addressing the central questions of political life under conditions of globalization, namely: who rules, in whose interests, by what mechanisms and for what purposes?

It is thus a vision of a global institutional architecture that is multilayered, pluralistic and structurally complex, with national governments still acting as strategic sites for enmeshing global governance. The shift from regimes to governance is also visible in global environmental politics, and much of the literature now talks about global environmental governance as the sphere of global environmental politics (Lipschutz 1996; Paterson et al. 2003). A move away from state-centric analysis has also occurred, with the focus on analyzing transnational environmental movements and NGOs as well as TNCs as actors in global environmental politics (see, for example, Princen and Finger 1994; Lipschutz 1996; Wapner 1996; 1997; Keck and Sikkink 1998; Bestill 2006). More recently, the co-creation of global environmental governance between state and non-state actors has been described as 'hybrid multilateralism' (Bäckstrand et al. 2017). 
There are a variety of theoretical approaches to global governance. The universalizing liberal language of global governance, as seen, for example, in the Report of the UN Commission for Global Governance (UNCGG), Our Global Neighbourhood, claims we are entering a new era of democratization, economic transformation, multilateralism and collective responsibility (UNCGG 1995: 1). While international governance was once played out in intergovernmental relationships, Our Global Neighbourhood claims this new global era is marked by the involvement of NGOs, citizens' movements, TNCs, and the global market alongside states and intergovernmental organizations

1995: 3). In the liberal academic literature, too, this inclusion of transnational actors in the policy-making process is what is perceived to be new about global governance (Young 1997).

Increasing transnational activism is attributed to the perceived powerlessness of the state in a globalizing world, particularly when it comes to so-called global issues, such as environmental degradation. Alongside the forces of globalization, pressure from grassroots movements is seen as a challenge to the power and authority of states (UNCGG 1995: 10-11). The response, according to the report, is for the states-system organized around a reinvigorated $\mathrm{UN}$ - to welcome these challenges in the form of a widened global governance. Non-governmental actors, according to the report, have brought about a 'global associational revolution' (1995: 253) consisting of 'a multitude of institutions, voluntary associations, and networks ...[which] channel the interests and energies of many communities outside government, from business and the professions to individuals' (UNCGG 1995: 32). 
Alongside NGOs, global business is considered to be an 'even more clearly identifiable sector with a role in global governance' (UNCGG 1995: 255). Business is seen as being 'in the forefront of "futures" research, mapping out long-range global scenarios and assessing their implications for corporate responsibility', following the lead of the Business Council on Sustainable Development (BCSD), which is 'illustrative of this new role' (Ibid). In this liberal, pluralist account, this wide range of non-governmental actors is seen as standing alongside states. Moreover, it is seen as enabling the democratization of global governance.

Critics of the liberal discourse caution that there is a danger of overemphasizing the diffusion, or even loss, of state power. The importance and centrality of state sovereignty do not disappear. The key institutions remain inter-governmental ones. Despite claims that environmental issues, because of their global nature, challenge the sovereign, interstate system, and despite claims to be creating some global civil space, the political framework of the liberal global political economy has not fundamentally altered. While states may appear to have lost autonomy, juridically their claim to sovereignty is not undermined (Paterson 1997: 175). Critical voices in the global governance debate draw connections to Foucauldian and neo-Gramscian discourse. Here, global governance does not mark the retreat of the state, but rather the ultimate form of government rationality or, as Foucault termed it, 'governmentality', the 'unspoken rationality of neoliberal globalization' (Douglas 2000: 116). Neo-Gramscians similarly liken global governance to a strategy of global capitalist hegemony, a process of institutionalization that stabilizes and perpetuates world order (Cox 1981: 136; Ford 2003: 122). In these views, global environmental governance is not so much about managing 
global environmental problems as about perpetuating dominant capitalist structures and practices. Yet again, other writers, recognising the complexity and diversity of global environmental governance, highlight the role of networks amongst a range of actors, deploying Social Network Analysis (SNA) to identify the complex structures of networks and how they might enable information flow, coordination and cooperation (Paterson 2016).

The space of global civil society

Within the literature on global governance, transnational actors are often said to be located within the sphere of global civil society. The concept of civil society itself is an old and complex one that has seen shifts over time in its boundaries with state and market, also varying theoretically from liberal to critical positions. However, as some authors have pointed out, there are problems with constructing bounded spheres due to the often transnational dimension of social relations (Shaw 1994). The extrapolation of civil society to global civil society is open to different interpretations. Predominantly, it is claimed that changing circumstances under conditions of globalization have affected non-state actors and the way they organize, as well as who and what they target. The sphere in which they are said to be operating has also become globalized. If national social movements were located in civil society, now transnational and global social movement activism is growing in a sphere of global civil society (see, for example, Shaw 1994; Lipschutz 1996). 
The term global civil society is now widely used amongst social movements, NGOs, business as well as government representatives and the institutions of global governance. It is actively shaping a political sphere and creating new transnational political identities and subjects (Drainville 2004). Some writers see global civil society as consisting of 'self-conscious constructions of networks of knowledge and action, by decentred local actors, that cross the reified boundaries of space as though they were not there' with the aim 'to reconstruct, re-imagine, or re-map world politics' (Lipschutz 1992: 390). In his view, global civil society is a parallel sphere that seeks to bypass the state-system and construct 'new political spaces' (1992: 393).

This leads to questions about what the sphere of global civil society adds to our analysis of transnational actors. Different theoretical viewpoints have different takes on the meaning and importance of global governance and global civil society. The dominant liberal view, as depicted in documents such as Our Global Neighbourhood, envisages a pluralistic, relatively harmonious, emancipatory political sphere (see also; Wapner 1997; Kaldor 2003). Liberals refer to it as that 'domain that exists above the individual and below the state but also across state boundaries, where people voluntarily organize themselves to pursue various aims' (Wapner 1997: 66). In this view, global governance is constituted by the addition of global civil society to international society, made up of both NGOs and business actors. It is portrayed as a space of 'civility' and not a potential site for conflicting interests.

On the other hand, traditional IR theorists are sceptical about the importance of global governance or global civil society (for example Grieco and Ikenberry 2003). They see 
any institutional mechanisms above the state level as inevitably subject to distortion and abuse by the most powerful nation-states who will further their interests through these institutions or ignore and bypass them.

Critical voices agree partially with some of the realist analysis about the abuse of such institutional mechanisms by powerful states, but they locate the whole scenario within global capitalism, seeing powerful states as seeking to expand their control over global capitalism, not just for the sake of political power in and of itself. Neo-Gramscians, for example, emphasize the role of ideology as well as institutions in maintaining capitalist hegemony. Here, the sphere of global civil society is in danger of contributing to the enclosure of the global public sphere, by creating an elite space that legitimizes global governance. However, the neo-Gramscian view also sees global civil society as a site for potential contest to hegemony, and thus a site of struggle and resistance. They see global civil society as the terrain where progressive forces are challenging the increasing power of capital and seeking to create transnational links and new political spaces for mobilizing on global problems such as social injustice and environmental degradation (for example Gill 2003).

In line with the perceived transformative potential of global civil society, sections of social movements - in particular established NGOs - consciously define themselves as members of global civil society, invoking the language of democratization and participation. They see the sphere of global civil society as a political space for engaging with the institutions of global governance in an attempt to make up for the democratic deficit that these non-transparent and unaccountable institutions create. Civil society actors 
clearly are active and important participants in a less state-centric global environmental governance, though claims that they democratise, or even lend greater legitimacy, require careful scrutiny (Bernauer and Betzold 2012; Stevenson and Dryzek 2014), and further investigation into the impact of transnational actors shows varying degrees of success (Betsill and Corell 2008; McCormick 2011; Newell 2000; Park 2013).

On the other hand, less institutionalized grassroots movements with radical agendas are suspicious of a politics of engagement, which they view as a form of co-optation (Ford 2003). In the neo-Gramscian view, the establishment of an enlarged liberal sphere of global civil society where people can participate in the management of the environment is consistent with the notion that civil society is a mechanism of hegemony. In this view, civil society's involvement and perceived contribution to policy making are a concession to the people in return for their acquiescence in preserving the dominant social, political and economic capitalist model. Further, they see such discourses of global civil society as strategies for absorbing and neutralizing potentially counterhegemonic ideas (Cox 1993: 55). However, they also stress that civil society is the space for change; the space where hegemony is challenged. It is where the struggle over environmental policy is played out. Global civil society thus is not only a sphere of action, but it has agency, as do the actors operating from the sphere, be they transnational environmental movements, TNCs or transnational business networks.

We saw that there are different interpretations of the phenomenon of global civil society and its democratizing potential. While one can argue that there has, indeed, been an increase in activity of transnational actors in the sphere of global civil society and, therefore, increased participation of these actors in global governance, that does not 
necessarily translate into democracy; although some argue it could potentially enhance democracy within global governance (for example Held and McGrew 2003; Stevenson and Dryzek 2014). Reports such as Our Global Neighbourhood may be slightly exaggerating the claims of democratization because participation does not necessarily equal representation. Here, NGOs are situated in the same sphere as business actors, competing for participation in global institutions. Previously, the UN's Agenda 21 had, for the first time ever, called upon the global population to participate in the saving of the planet (UN 1992). However, the locus of authority remains entrenched in the interstate system, with a growing recognition of the role of business as by far the dominant section of this so-called global civil society. Critical scholars view environmental issues as being depoliticized through the orthodox discourse of global environmental governance building within the liberal global political economy (e.g. Paterson 2000). That is to say that environmental problems are separated out from economic and political issues, seen as discrete issues that are capable of being fixed through institutions, market-based mechanisms or changed behaviour, yet without challenging the parameters of the current system.

At heart, the study of the role of transnational actors in global environmental politics is about power relations. As we saw above, global environmental governance is the arena of global environmental politics. It is here that the global management of transboundary environmental issues is fought out. Global civil society is now most readily identified as the space in which transnational actors operate. It is portrayed as a democratizing force for global governance in the dominant liberal literature. However, critical scholars want to deconstruct this space and make the power relations explicit. Ultimately, we might 
want to ask in what way does an analysis of transnational actors in global environmental politics challenge conventional approaches to understanding political outcomes in global environmental politics. For this, we now turn to an illustration of a variety of transnational actors.

\section{Transnational actors in global environmental politics}

The previous section has illustrated the context and space of transnational activism. Traditionally, the role of transnational actors in the policy-making process, like in the discipline of IR more generally, has not been at the centre of analysis. Although regime theory, in its analysis of environmental regimes and multilateral environmental agreements, acknowledges epistemic communities as contributors to global environmental politics, the emphasis has been on the role of scientists and technical experts contributing expertise to the understanding of environmental issues (Vogler 2003). This has been particularly important where controversy or uncertainty has been an issue, for example over the phenomenon of climate change. The presence of epistemic communities, however, has not radically unsettled the state-centricity of regime analysis. While it has introduced actors other than states, these have been limited to elite experts. These types of elite actors must not be confused with the broader transnational environmental movement and might better be described as part of broader advocacy networks (Keck and Sikkink 1998).

This section will focus on transnational environmental movements, NGOs and 
transnational business/TNCs as actors in global environmental politics. It will use the concept of NGOs generally, although they are sometimes also referred to as International NGOs (INGOs) or Transnational NGOs (TNGOs). Although this book's focus is on global environmental politics, and the focus of this chapter is on the transnational actors in global environmental politics, this is not to say that environmental issues can be seen in isolation. Indeed, focusing on single issues can be counterproductive because it may fail to challenge the fragmented, disciplinary technical-rational discourse that is a key contributor to environmental degradation and current global environmental governance. If environmental issues are separated out of their social, political and economic context, the root causes are rendered invisible, leading to techno-fix solutions that may exacerbate the problem (Ford 2003). Indeed, concerns amongst transnational actors are rarely limited to discrete environmental problems. The analysis of global environmental change and issues of sustainability is mostly couched in a much broader framework, looking at the relationship between environment and human economic, social, cultural and political development. The growing discourse around environmental and ecological justice exemplifies this (Gillard et al. 2017).

\section{Transnational environmental movements and NGOs}

Particularly since the 1960s, global environmental movements have proliferated with the awareness and politicization of environmental degradation and its relationship to the wider organization of modern societies in their economic, political and cultural aspects. Increased awareness around the connection between globalization and environmental 
degradation has led movements to take their struggle out of a purely national context. The 1992 UN Conference on Environment and Development (UNCED) is usually quoted as the watershed for transnational actor involvement in global environmental politics, where close to 1,500 NGOs organized a parallel conference and many more movements and NGOs rallied from across the globe. Ten years later, over 6,000 officially registered NGOs gathered in Johannesburg for the 2002 International Summit on Sustainable Development, alongside countless 'unofficial' groups and movements. A myriad of movements and organizations across the world, from business to NGOs, campaigned on climate change around the various Conferences of the Parties COPs running up to the Paris Climate Conference in 2015.

It is hard to find a consensus among social movement theorists as to how a social movement might be defined. Scholars have challenged the social movement literature that has tended to see social movements as bounded by nation-states, or geographically limited to regions or cultures, particularly the North (see, for example, Walker 1994; Stammers and Eschle 2005). Broadly, social movements, including environmental movements, are heterogeneous groups that share collective identity, solidarity and common purpose (e.g. Diani 2000). They vary in size, issues and tactics and the environmental movement itself spans various shades of green. Despite the diversity of identities and experiences, these movements do identify commonalities in the experience of late capitalist modernity and connections are sometimes forged across space and place. Transnational movements, then, are movements that are building transnational cooperation around common goals and purposes (Smith et al. 1997: 59-60). Sydney Tarrow 
defines them as: ' ...socially mobilised groups with constituents in at least two states, engaged in sustained contentious interactions with power-holders in at least one state other than their own, or against an international institution, or a multinational economic actor' (2001: 11).

Thus, transnational environmental movements are movements that are creating transnational links and acting transnationally because they perceive the root causes of environmental degradation to be tied up with the forces of globalization, such as the increasing globalization of capital and, with it, the globalization of governance structures. That said, there are many movements that campaign solely on national, regional or local issues. But, increasingly, there is an awareness of the relationship between the local and the global. Indeed, 'think global act local' became a prominent slogan within the green movement, linking global awareness with the importance of connectedness to place and rooted action, as seen, for example, in the Transition Movement (for example Griffiths 2009).

Figure 2.1. 'Women's Call for Calm' 15 minute silence at the site entrance at the Preston New Road Cuadrilla fracking site, Lancashire, 12 July 2017. Photo courtesy of Peter Yankowski

While many movements campaign on specific issues, it is important to note that the boundaries between issues are not necessarily always rigid. Transnational movements campaigning on human rights abuses, gender inequality or labour issues often share similar concerns and goals to environmental movements, in that their individual causes may all in some ways stem from the nature of the current global economic and political system. Indeed, many environmental movements would not want to separate the 
environment and human development. They argue that sustainability and social justice go hand in hand.

The terminology for describing transnational movements has varied enormously: for example, INGOs, International Social Movement Organizations (ISMOs), international pressure groups or interest groups, or transnational advocacy groups or networks (e.g. Keck and Sikkink 1998; Stammers and Eschle 2005). Within the field of the environment more specifically, they have been described as environmental transnational coalitions (Princen 1995). More broadly, they have been identified as world civic politics (Wapner 1996), global citizen action (Edwards and Gaventa 2001) or people's movements (Shiva 2005). Many movements have identified globalized capitalist structures and distant, unaccountable governance structures as part of the problems they care about and have identified themselves as anti-globalization movements, anticapitalist movements, pro-democracy movements, and global justice movements or, more boldly, the 'movement of movements' (Mertes 2004).

There is a danger of conflating organizations with movements (Stammers and Eschle 2005). The environmental movement broadly conceived contains a wide variety of groupings. While some NGOs could be seen to be located on a spectrum within the environmental movement, it is not the case that all NGOs are part of the movement as such. Some large, established NGOs, such as IUCN (International Union for the Conservation of Nature) or the WWF (World-Wide Fund for Nature), have a high 
degree of cross-fertilization with established institutions of governance. These large, bureaucratic, professional environmental NGOs are far removed from the grassroots of the environmental movement, though they may share common concerns.

Others, such as pressure groups like Friends of the Earth or Greenpeace, are financially independent of governmental institutions and sometimes take an anti-state position as well as lobbying at the state and inter-state level. As such, they have a two-pronged approach. On the one hand, they have been involved, along with organizations such as IUCN and WWF, in setting and monitoring the implementation of institutional responses, in the context of international environmental regime formation and maintenance and within the United Nations as well as within national governments or at the EU level. On the other, they are working in solidarity with grassroots environmental movements, sometimes taking direct action (Young 1999; Ford 2003).

Grassroots movements are largely marginalized from institutional processes, often by choice. They might not fit neatly into a 'transnational' category because they may be campaigning on a particular local issue and may lack resources to network transnationally. However, they clearly identify transnational structures as the root cause of environmental destruction. Movements such as Via Campesina, Climate Camp or Earth First! are challenging the top-down governance process through direct action. They are highly critical of the institutional channels available and their responses to environmental problems. They are also critical of institutionalized environmental NGOs that they see as co-opted by the dominant powers of global governance. These grassroots activist movements perceive themselves to be engaged in an emancipatory 
struggle for freedom from dominating discourses to pursue alternative, equitable and sustainable ways of living, working for a redistribution of power and carving out political space. Their strategy is not necessarily to influence the agenda of the global governance process but rather to take direct action to increase awareness about issues and to directly challenge and confront the state and economic powers that be. Although they may be active in specific places and localities, they are forging transnational links through networks such as the Peoples' Global Action or the World Social Forum (Williams and Ford 1999; Ford 2003; Mertes 2004). The movement of movements could be seen as the transnational heart of a large variety of groups and movements across the globe. Within this movement, diverse groups from across the globe are campaigning for the preservation of economic, political, cultural and ecological diversity, which they perceive to be under threat from a globalizing monoculture (see Shiva 1993; Gill 2003).

The intention here is not to measure which movements have been most successful in, for example, lobbying the institutions of global governance or attempting to shut them down. Rather, the emphasis is on the political and cultural process of activism and the impediments which may be preventing successful outcomes, and on the portrayal of these movements as agents of change. Indeed, instrumentally, these movements may be relatively powerless compared to large business lobby groups. However, there is a powerful, cultural element to the movements for social change, which through global action and the global media, are spreading new discourses and challenging existing ones. 
Importantly, movements do not just arise as a means to an end but are actively engaged in processes of socio-cultural change, bringing forth alternative ways of knowing and doing. Progressive movements are thus not just challenging the organization of the global political economy but actively showing what an alternative could look like. This cultural aspect of social movements is something that has been largely ignored in social movement theory that focuses on the reasons for mobilization of collective behaviour.

Melucci (1996) has warned that social movements must not be reduced purely to a political dimension for this would deny the communicative role they play (p. 2). His project is concerned with analyzing the actors' construction of their own action (1996: 16), the actual processes of cultural change. Yet, such an approach must not lose sight of the context, which remains the global political economy. Social movements need to be reflexive about their position within this hegemony as well as the dangers of cooptation. As seen above, they need to be able to contextualize their agency within the global matrix.

TNCs and business advocacy groups

Like transnational environmental movements and NGOs, TNCs have mushroomed in the last three decades, and they constitute important players in the modern, hyperglobalized capitalist world economy, responsible for large amounts of investment and trade. A TNC is a corporation that is active in more than two countries - that is, it may have a host state, but it operates subsidiaries in various other locations and involves the movement of capital, resources and people across national boundaries. Examples might include oil corporations such as Shell or BP, or food giants such as Unilever or Nestle. 
Apart from TNCs, though, there are also related business advocacy groups who act in the interests of transnational business, such as the International Chamber of Commerce (ICC), the World Business Council for Sustainable Development (WBCSD) or the European Chemical Industry Council (CEFIC), to name a few examples.

TNCs and business advocacy networks are clearly important transnational actors in global environmental politics because of the close link between the global economic system and global environmental degradation. Unlike transnational movements and NGOs, they are pursuing instrumental goals rather than acting on principled beliefs (Keck and Sikkink 1998; Clapp 2005b). They are motivated by profit, which leads to the growth imperative and resulting increased demand on resources that can contribute directly to environmental degradation, given that many TNCs are operating in environmentally sensitive sectors, such as natural resource extraction. While some TNCs invest in and produce environmentally benign goods and services, generally trade and investment patterns within the capitalist global economy tend to exacerbate, rather than mitigate, environmental degradation due to the growth imperative. The distantiated processes of global capitalism, including the activities of TNCs, contribute both directly and indirectly to processes of environmental degradation. This leads to a tension between global environmental governance as pursued through MEAs and the freedom to do business. TNCs and transnational business advocacy networks acting on their behalf are eager to minimize regulation that is designed to limit environmental (and social) degradation. Fundamentally, then, there is a conflict of interest between their aims and those of global environmental policy. Like NGOs, they are involved in lobbying within the global environmental policy-making process, though they are often pursuing very 
different outcomes from those of NGOs. While NGOs and social movements may be seeking to challenge the very culture of capitalist relations that systematically produce environmental degradation and social injustice, TNCs are attempting to influence the agenda to prevent measures that could be harmful to business. There is no denying the power of TNCs, as some TNCs have greater assets than nation-states. However, not all commentators see TNCs as necessarily an obstacle to sustainable development. Some argue that these assets can be used to positively contribute to sustainable development, such as through the transfer of innovative and clean technology and the investment in infrastructure and job creation (Murphy and Bendell 1997, Herman, Chapter 9 in this volume). In this way, the world has seen a greening of some businesses.

The greening of business or greenwash?

Apart from official lobbying in opposition to global environmental policy, business has also been very busy recreating itself as a vanguard of sustainable development (Schmidheiny 1992; ICC 1991). The institutionalization of this concept is not limited to governments and international organizations. In addition to UN documents and government policies, the concept of sustainable development has entered the corporate world. However, business is not blind to the environmental movement's criticisms and, in the concept of sustainable development, has found a way to discursively integrate environmental problems without substantially changing its social and material productive practices. The link between economic growth and environmental degradation remains solid, despite the corporate sector's promotion of sustainable development (ICC 1991). 
During the 1992 UNCED conference, business was brought on board and the WBCSD (formerly the BCSD) was born. This lobby group managed to ensure that, during official negotiations, the role of business in environmental degradation was played down. Agenda 21, signed at UNCED as a comprehensive blueprint for global action on sustainable development (UN 1992), only mentions corporations in order to emphasize their role in sustainable development but eschews any mention of the need for business to be regulated. More fundamentally, at the same time as UNCED was being held, UN reforms were underway that dismantled the United Nations Centre on Transnational Corporations (UNCTC) (Clapp 2005a: 25). Attempts by the UNCTC to include corporate accountability measures within Agenda 21 had been rejected by industrialized countries during preparatory meetings. The controversy over the lack of provisions in Agenda 21 regarding corporations was further enhanced by the fact that corporations such as ICI (Imperial Chemical Industries) and ARCO (Atlantic Richfield Company), major environmental polluters with a track record of funding anti-environmental lobby groups, were found to be contributing to the funding of UNCED itself (Doran 1993; Chatterjee and Finger 1994).

Critical voices would argue that business is using the discourse of sustainable development as a way of subverting environmental concerns through greenwash (Beder 1997). As far back as 1984, UNEP (the United Nations Environment Programme) and ICC organized the World Industry Conference on Environmental Management (WICEM), which three years prior to the Brundtland Report's promotion of sustainable development, was discussing the possibility of achieving economic growth and sound environmental management. The position was a distinctly corporatist one. At WICEM, 
it was recommended that industry should become more strongly involved in formulating environmental policy in general, as well as in formulating national environmental regulatory frameworks (Trisoglio and ten Kate 1991). By 1991, in the run up to UNCED, WICEM II was clearly carving out the niche for industry in defining and spearheading their particular model of sustainable development.

As part of this quest, WICEM II further called on business and industry to foster harmonious relations with local communities in order to gain their confidence and to become better integrated into the community and wider society. The result of WICEM II was The Business Charter for Sustainable Development: Principles for Environmental Management, adopted in 1990 and first published in 1991. This states, for example,

economic growth provides the conditions in which protection of the environment can best be achieved, and environmental protection ... is necessary to achieve growth that is sustainable...In turn, versatile, dynamic, responsive and profitable businesses are required as the driving force for sustainable economic development and for providing managerial, technical and financial resources to contribute to the resolution of environmental challenges. Market economies, characterised by entrepreneurial initiatives, are essential to achieve this...making market forces work in this way to protect and improve the quality of the environment - with the help of standards such as ISO 14000, and judicious use of economic instruments in a harmonious regulatory framework - is an ongoing challenge that the world faces in entering the 21 st century. 
It is clear from this passage that business, in line with conventional economic orthodoxy, perceives environmental degradation to be something outside of economic processes. The environment is something that is separate from, and that impinges on and challenges, economic and corporate structures and processes. Business and growth cannot be questioned in themselves, the task is to 'manage' the challenges within the given framework. Business is clearly bidding for its narrow view of sustainable development to be implemented and for business to take on a major role in the implementation. While, on the one hand, aiming to become more closely integrated with community and society, business is actually lobbying for autonomy and self-regulation or, at most, market-based instruments such as carbon-trading.

\section{The privatization of global environmental governance}

Another key dynamic in the provision of global public goods has been that of public authority versus private power. Global governance has sometimes involved a shift away from public authority to private agencies, as seen, for example, in the public-private partnerships such as Global Compact, which includes over 4,700 corporate participants as well as stakeholders from over 130 countries. At heart, it advocates responsible corporate citizenship to the challenges of globalization in the areas of human rights, labour, environment and anti-corruption, contributing to a more sustainable and inclusive global economy (UNGC no date).

Likewise, business advocacy groups, such as WBCSD, and institutions, such as the 
International Organization for Standardization (ISO), promote voluntary codes of conduct that, as well as safeguarding the autonomy of business, also implicate business in environmental management. The growth in voluntary codes of conduct is blurring the boundary between public and private and leading to what has been called 'mixed regimes', involving states and private authorities in the 'creation and maintenance of international principles, norms, rules and decision-making procedures' (Clapp 1998: 295).

There has been a tension between the general liberalization and deregulation trend in the globalized political economy on the one hand and the growing need for environmental regulation on the other, which has led to a search for 'new and private forms of (environmental) regulation, such as (environmental) standards ... as a way out of this tension between deregulation and re-regulation' (Finger and Tamiotti 1999: 9). On the one hand, there has been a move from traditional 'command and control' style policy to an increased privatisation of environmental politics involving the private sector and non-state actors (see also Clapp 1998). On the other, there is an argument that a fundamental reorganization of international society is taking place, as seen in the growth of global governance (Finger and Tamiotti 1999).

A privatization of environmental governance is taking place, as seen in the growing influence of private actors on decision making, which in some cases, is outweighing the influence of states. Evidence suggests that more and more private actors are initiating regimes which are later recognized by states and incorporated into their regulatory 
structures, one example being the ISO 14000 series, which specifies environmental management standards (Clapp 1998). In line with the mainstream belief that global environmental problems demand global solutions, the notion of global standards would seem an essential basis upon which to build harmonized global solutions. However, also in line with the mainstream, it ignores the unequal power structures within the global political economy. The membership of ISO, true to its hybrid nature, consists of a mixture of governments, mixed public-private actors and private industry associations. The government members are predominantly made up of developed countries, while the private members' majority come from within the OECD (Organisation for Economic Co-operation and Development). Given that the decision-making process is heavily dominated by private interests, the voice of developing countries in the establishment of these global standards is marginalized (Clapp 1998: 296-301).

The idea of establishing environmental standards within the remit of ISO was a response to Agenda 21's recommendation for the role of industry in sustainable development (Clapp 1998: 302). The setting up of environmental management standards involved a change of direction from the ISO's traditional remit of technical standards (Finger and Tamiotti 1999: 12).

The shift towards global standards must further be seen in the context of trade liberalization and the WTO (World Trade Organization). The WTO's Agreement on Technical Barriers to Trade (TBT) encourages the use of international standards rather than 
national ones, which are seen as technical barriers to trade (Finger and Tamiotti 1999: 13; Clapp 1998: 305). In effect, the ISO environmental management standards, which were recognized by the GATT (General Agreement on Tariffs and Trade), create a lowest common denominator and act as a mechanism for avoiding trade barriers. More importantly, they demonstrate the role of privately agreed voluntary standards in the re-regulation and public management of international trade.

With the latest global crisis in neoliberal capitalism and a seeming return to neoKeynsian style intervention, some green voices are proposing a 'Green New Deal' as a solution to the interlinked crises of capital, energy and climate. This would involve business and government as well as labour and environmental movements in bringing about a shift to green energy and green collar jobs financed by re-regulating finance and taxation (GNDG 2008).

From the above, we can see that transnational environmental movements and TNCs and their advocates and lobbyists are all clearly visible actors in global environmental politics. The question of the power of these diverse actors in global civil society is a complex one. For one, we have seen that this sphere includes a large variety of different types of actors - NGOs, transnational advocacy groups, TNCs, social movements. The liberal pluralist descriptions of this sphere do not analyze power relations within civil society. It seems questionable that business actors and NGOs are working on an equal footing. Business actors clearly have more 'tacit power' over state actors due to their close connection to economic growth creation (Newell 2000: 159). Further, amongst 
NGOs themselves, there are differentiations that cannot be ignored. NGOs, like social movements, are not a homogeneous, or necessarily a progressive, force and are not immune to power relations of class, race or gender or between North and South and are further differentiated on the basis of ideologies and strategies. Critical voices, on the other hand, embrace the diversity and complexity of the sphere, seeing it as a site of struggle for hegemony as well as counter-hegemony.

\section{Conclusions}

This chapter has provided an overview of transnational actors and their agency in global environmental politics. Over the last two decades, we have seen a growing literature on the role of transnational actors in world politics. Few IR scholars would argue that they are completely irrelevant. Most would agree that transnational actors need to be part of the analysis in understanding the framework and processes of global politics. Transnational actors are, of course, a broad church, encompassing anything from transnational social movements to global business. They do not all operate on the same footing, nor do they employ the same tactics to achieve their goals. Different theoretical perspectives provide different analyses of how and why transnational actors matter to global environmental politics. Solving global environmental problems is clearly a political as well as an economic, cultural and social struggle. States are not the only actors in this arena, and it is clear that transnational actors are an important part of the picture. 


\section{Recommended Reading}

Betsill, M. M. (2011) Transnational actors in international environmental politics, in

Betsill, M. M., Hochstetler, K. \& Stevis, D. (eds), Palgrave Advances in International Environmental Politics, 2nd edition. Basingstoke: Palgrave Macmillan.

Betsill, M. M. \& Corell, E. (2008) NGO Diplomacy: The Influence of NGOs in International Environmental Negotiations. Cambridge, MA: MIT Press.

Park, S. (2013) Transnational Environmental Activism, in Falkner, R. (ed), The Handbook of Global Climate and Environmental Policy. Chichester: Wiley \& Sons, 268-285.

\section{References}

Ambrose, J. (2017) Cuadrilla’s Fracking Plans Cleared by High Court. The Telegraph, 12 April. Available at: http://www.telegraph.co.uk/business/2017/04/12/cuadrillaslancashire-fracking-plans-cleared-high-court (last accessed 19/07/2017).

Bäckstrand, K., et al. (2017) Non-State Actors in Global Climate Governance: From Copenhagen to Paris and Beyond. Environmental Politics, 26(4), 561-579.

Beder, S. (1997) Global Spin: The Corporate Assault on Environmentalism. Totnes: Green Books.

Bernauer, T. \& Betzold, C. (2012) Civil Society in Global Environmental Governance. The Journal of Environment and Development, 21(1), 62-66.

Betsill, M. M. \& Corell, E. (2008) NGO Diplomacy: The Influence of NGOs in International Environmental Negotiations. Cambridge, MA: MIT Press.

Chatterjee, P. \& Finger, M. (1994) The Earth Brokers. London: Routledge. 
Clapp, J. (1998) The Privatisation of Global Environmental Governance: ISO 14000 and the Developing World. Global Governance, 4, 295-316.

Clapp, J. (2005a) Global Environmental Governance for Corporate Responsibility and Accountability. Global Environmental Politics, 5(3), 23-34.

Clapp, J. (2005b) Transnational Corporations and Global Environmental Governance, in Dauvergne, P. (ed.), Handbook of Global Environmental Politics. Cheltenham: Edward Elgar.

Cox, Robert W. (1981). Social Forces, States and World Orders. Millennium 10 (2): 126-151.

Cox, R. (1993) Gramsci, Hegemony and International Relations: An Essay in Method, in Gill, S. (ed.), Gramsci, Historical Materialism and International Relations. Cambridge:CUP.

Diani, M. (2000) The Concept of Social Movement, in Nash, K. (ed.), Readings in Contemporary Political Sociology. Oxford: Basil Blackwell.

Douglas, I. (2000) Globalization and the Retreat of the State, in Gills, B. K. (ed.), Globalization and The Politics of Resistance. Basingstoke: Macmillan.

Doran, P. (1993) The Earth Summit (UNCED): Ecology as Spectacle. Paradigms: The Kent Journal of International Relations, 7(1), 55-65.

Drainville, A. (2004) Contesting Globalization: Space and Place in the World Economy. London: Routledge.

Edwards, M. and Gaventa, J. (eds) (2001) Global Citizen Action: Lessons and Challenges, London: Earthscan.

Eilperin, J. and B. Dennis (2017) ' Trump Administration to approve final permit for Dakota Access Pipeline' Washington Post, 07/02/2017, Available at: 
https://www.washingtonpost.com/news/energy-environment/wp/2017/02/07/trump-

administration-to-approve-final-permit-for-dakota-access-

pipeline/?utm term=.b54d53055ae3 (last accessed 25/08/17).

Finger, M. \& Tamiotti, L. (1999) New Global Regulatory Mechanisms and the Environment: The Emerging Linkage between the WTO and the ISO. IDS Bulletin, 30(3), 815.

Ford, L. H. (2003) Challenging Global Environmental Governance: Social Movement Agency and Global Civil Society. Global Environmental Politics, 3(2), 120-134.

Gill, S. (2003) Power and Resistance in the New World Order. Basingstoke: Palgrave Macmillan.

Gillard, R., Ford, L. \& Kütting, G. (2017) Justice Discourses and The Global Environment: Diverse Perspectives on an Uneven Landscape, in O. Corry \& H. Stevenson (eds), Traditions and Trends in Global Environmental Politics: International Relations and the Earth. London: Earthscan.

GNDG (Green New Deal Group). (2008) A Green New Deal: Joined Up Policies to Solve the Triple Crunch of the Credit Crisis, Climate Change and High Oil Prices. London: New Economics Foundation.

Grieco, J. M. \& Ikenberry, G. J. (2003) State Power and World Markets. New York and London: Norton.

Griffiths, J. (2009) The Transition Initiative: Changing the Scale of Change. Orion Magazine, July/August. Online. Available at: http://www.orionmagazine.org/index.php/articles/article/4792 (last accessed 29/06/2009). 
Held, D. \& McGrew, T. (eds). (2003) The Global Transformations Reader. Cambridge: Polity.

ICC (International Chamber of Commerce) (1991) The Business Charter for Sustainable Development: Principles for Environmental Management. Paris: ICC, leaflet.

Kaldor, M. (2003) Global Civil Society. Cambridge: Polity.

Keck, Margaret E. and Kathryn Sikkink (1998) Activists Beyond Borders: Advocacy Networks in International Politics, Ithaka/London:Cornell University Press.

Keohane, R. \& Nye, J. (1977) Power and Interdependence. Boston: Little, Brown and Company (Inc.).

Lipschutz, R.D. (1992) 'Reconstructing World Politics: The Emergence of Global Civil Society', Millennium, 21(3), pp. 389-420.

Lipschutz, Ronnie D. with Judith Mayer (1996) Global Civil Society and Global Environmental Governance, Albany:SUNY.

McCormick, J. (2011) The Role of Environmental NGOs in International Regimes, in Axelrod, R. et.al. (eds), The Global Environment: Institutions, Law and Policy. Washington, DC: CQ Press, 92-109.

Melucci, A. (1996) Challenging Codes: Collective Action in the Information Age. Cambridge: CUP.

Mertes, T. (ed.) (2004) A Movement of Movements: Is Another World Really Possible? London: Verso.

Murphy, D. F. \& Bendell, J. (1997) In the Company of Partners: Business, Environmental Groups and Sustainable Development Post-Rio. Bristol: Policy.

Newell, P. (2000) Climate for Change: Non-State Actors and the Global Politics of the Greenhouse. Cambridge: CUP. 
Our Revolution. (2016) Statement on Army Corp's Decision to Block Dakota Access

Pipeline Route. Available at: https://ourrevolution.com/press/our-revolution-armycorps-decision-block-dakota-access-pipeline-route/ (last accessed 19/07/2017).

Park, S. (2013) Transnational Environmental Activism, in Falkner, R. (ed.), The Handbook of Global Climate and Environmental Policy. Chichester: Wiley \& Sons, 268-285.

Paterson, Matthew (1997) 'Institutions of global environmental change: sovereignty', Global Environmental Change, Vol. 7, No.2, pp. 175-177.

Paterson, M. (2000) Understanding Global Environmental Politics. Basingstoke: Palgrave Macmillan.

Paterson, M. (2016) Networks and Coordination in Global Climate Governance, in Stavins, R. N. \& Stowe, R. C. (eds), The Paris Agreement and Beyond: International Climate Change Policy Post-2020. Harvard Kennedy School Project on Climate Agreements, 83-86.

Paterson, M., Humphreys, D. \& Pettiford, L. (2003) Conceptualising Global Environmental Governance: From Interstate Regimes to Counter-Hegemonic Struggles. Global Environmental Politics, 3(2), 1-10.

Princen, T. \& Finger, M. (1994) Environmental NGOs in World Politics. London: Routledge.

Princen, T. (1995) 'Ivory, conservation and environmental transnational coalitions', in T. Risse-Kappen (ed) Bringing Transnational Relations back in: Non-state actors, domestic structures and international institutions, Cambridge: CUP, pp. 227-256.

Schmidheiny, S. (1992) Changing Course. Cambridge, MA: MIT Press.

Scott, A. (1990) Ideology and the New Social Movements. London: Unwin Hyman. 
Shaw, M. (1994) Civil Society and Global Politics: Beyond a Social Movements Approach. Millennium, 23(3), 647-667.

Shaw, M. (2000) Theory of the Global State: Globality as Unfinished Revolution. Cambridge: CUP.

Shiva, V. (1993) Monocultures of the Mind. London: Zed Books.

Shiva, V. (2005) From Doha to Hong Kong via Cancun. Online. Available at: https://zcomm.org/znetarticle/from-doha-to-hong-kong-via-cancun-by-vandana2-shiva/ (last accessed 20/01/2009).

Smith, J., Pagnucco, R. \& Chatfield, C. (1997) Social Movements and World Politics: A Theoretical Framework, in Smith, J., Chatfield, C. \& Pagnucco, R. (eds), Transnational Social Movements and Global Politics. Syracuse: Syracuse University Press.

Stammers, N. \& Eschle, C. (2005) 'Social Movements and Global Activism', in de Jong, W., Shaw, M. \& Stammers, N. (eds), Global Activism Global Media. London: Pluto.

Stevenson, H. \& Dryzek, J. S. (2014) Democratising Global Climate Governance. Cambridge and New York: Cambridge University Press.

Tarrow, S. (2001) 'Transnational politics: contention and institutions in International Politics', in Annual Review of Political Science, Vol.4, pp. 1-20.

Trisoglio, A. \& ten Kate, K. (1991) From WICEM to WICEM II: A Report to Assess Progress in the Implementation of the WICEM Recommendations. Geneva: UNEP.

TWN (Third World Network) (no date) WTO_-Shrink or Sink. Online. Available at: (http://www.twn.my/title/shrink.htm last accessed 12/12/2008).

UN (1992) Agenda 21. UNCED, Geneva: UN. 
UNCGG (UN Commission on Global Governance) (1995) Our Global Neighbourhood.

Oxford: OUP.

UNGC (UN Global Compact) (no date) Online. Available at:

http://www.unglobalcompact.org/AboutTheGC/index.html (last accessed 15/01/2009).

Vogler, J. (2003) Taking Institutions Seriously: How Regime Analysis can be Relevant to Multilevel Environmental Governance. Global Environmental Politics, 3(2), 25-39.

Walker, R. B. J. (1994) Social Movements/World Politics. Millennium, 23(3), 669-700.

Wapner, P. (1996) Environmental Activism and World Civic Politics. Albany: SUNY.

Wapner, Paul. (1997). Governance in global civil society. In Global Governance:

Drawing Insight from the Environmental Experience, edited by Oran Young, 65-84.

Cambridge MA: MIT Press

Williams, M. \& Ford, L. (1999) The World Trade Organisation, Social Movements and

Global Environmental Management, in Rootes, C. (ed.), Environmental Movements Local, National, Global. London: Frank Cass.

Wong, J. C. (2016) Dakota Access Pipeline: US Denies Key Permit, A Win for Standing Rock Protesters. The Guardian, 5 December. Available at:

https://www.theguardian.com/us-news/2016/dec/04/dakota-access-pipeline-permitdenied-standing-rock (last accessed 19/07/2017).

Young, O. R. (ed.) (1997) Global Governance: Drawing Insights from the Environmental Experience. Cambridge, MA: MIT Press.

Young, Z. (1999) NGOs and the Global Environmental Facility: Friendly Foes, in Rootes, C. (ed.), Environmental Movements Local, National, Global. London: Frank Cass. 
1 I would like to thank Peter Doran, Jenneth Parker, Stephen Hurt and Neil Stammers for feedback on the first edition of this chapter. 